\title{
EFFECT OF POTASSIUM ON BORO-FALLOW-T. AMAN CROPPING PATTERN IN OLD BRAHMAPUTRA FLOODPLAIN SOIL OF BANGLADESH
}

\author{
M. R. Islam*, H. Afroz, R. Pervin, F. Ansari, M. H. Rahman ${ }^{1}$ \\ Department of Soil Science, Bangladesh Agricultural University, Mymensingh-2202, Bangladesh
}

\begin{abstract}
Field experiment was conducted at the Bangladesh Institute of Nuclear Agriculture (BINA) farm, Mymensingh during 2010-11 to 2011-12 to investigate the effect of different levels of $\mathrm{K}$ on Boro-Fallow- $\mathrm{T}$. Aman cropping pattern in Old Brahmaputra Floodplain Soil of Bangladesh. There were four treatments for the first crop (Boro rice): $\mathrm{T}_{1}$ (Control), $\mathrm{T}_{2}$ (50\% NPKS), $\mathrm{T}_{3}(75 \% \mathrm{NPKS})$ and $\mathrm{T}_{4}(100 \%$ NPKS). The $100 \% \mathrm{NPKS}$ rates were recommended on the basis of soil test values. $\mathrm{T}_{4}$ treated plot of each block was further split into seven sub-plots to represent seven treatments $\left(T_{4.1}\right.$ to $\left.T_{4.7}\right)$ for the second crop of $T$. Aman in the sequence. The results reveal that the grain yield of boro rice varied from 2.33 to $6.00 \mathrm{t} \mathrm{ha}^{-1}$ of which the highest yield was recorded with the application of $100 \%$ NPKS $\left(T_{4}\right)$ and the lowest with $T_{1}$ (control). The effect of boro rice straw removal or incorporation was clearly visible on the following crop, T. Aman rice. The highest grain and straw yields of T. Aman were obtained with $\mathrm{T}_{4.4}$ treatment, where $75 \%$ straw was removed and $25 \%$ straw incorporated with soil. The lowest yield was obtained with the control crop without fertilizer or straw residues. The NPKS uptake by T. Aman rice and benefit : cost ratio supported the dominant performances of $\mathrm{T}_{4.2}(100 \% \mathrm{NPS}+50 \% \mathrm{~K}+25 \%$ boro rice straw removed). The results suggested that it is possible to reduce $\mathrm{K}$ mining from soils as well as to reduce the rate of $\mathrm{K}$ fertilizer application, substituting by incorporation of rice straw residues in soil system.
\end{abstract}

Key words: Boro-T. aman sequence, Potassium levels \& uptake, Old Brahmaputra Floodplain, Rice residues and Yield

\section{INTRODUCTION}

Potassium is often described as the "quality element" for crop production as is necessary for basic physiological formation of sugar and its subsequent movement

\footnotetext{
* Corresponding author email: mrislam69@yahoo.com

${ }^{1}$ Soil Science Division, Bangladesh Institute of Nuclear Agriculture, Mymensingh-2202, Bangladesh
}

Received: 22.05.2014 
among different parts, synthesis of protein, cell division and growth (Rao et al., 1990). Proper fertilization effectively improves quality and yield of crops, reduce cost, which augmenting farm income. On the contrary, improper fertilization not only reduces crop yield and quality, but also increases cost, reduce and effectiveness of fertilizer use.

The widespread problem of $\mathrm{K}$ deficiency as well as $\mathrm{K}$ mining due to intensive cropping with HYVs of rice and nutrient imbalance in soil, which can be minimized by judicial application of potassium fertilizer. Higher yield of rice with higher dose of $\mathrm{K}$ over the present recommended rate was reported by many workers (Mitra et al., 2001; Sairam et al., 2002; Singh et al., 2006 and Bahmaniar et al., 2007). In the BINA farm soil it is necessary to find out the optimum rate of potassium application for profitable rice production.

Potassium is considered to be the second element in uptake by most of the agricultural crops. On the other hand, there exists a gap between annual $\mathrm{K}$ removal by the crops and $\mathrm{K}$ addition through external sources. It would be very optimistic part to expect that this deficit of $\mathrm{K}$ will be balanced from the native and organic sources. If it is not being stress out the adequate use of potassium in crop production, this gap will widen further with increased target of food production. As evidenced by research findings, a large percentage of sterile or unfilled spikelets are caused by poor pollen viability and this retards carbohydrate translocation due to potassium deficiency (Dobermann and Fairhurst, 2000). Removal of potassium is higher by the modern varieties than the traditional ones. Removal of straw from the field is widespread in Bangladesh, which explains the depletion of soil $\mathrm{K}$ reserves at many sites. Straw is the only organic material available in significant quantities to the most rice farmers. Rice straw contains more K compared to other nutrients and therefore it can be used as a source of $\mathrm{K}$ supply to crops. Keeping with this in view, the present study designed with different levels of $\mathrm{K}$ along with rice straw of previous crop and with other recommended fertilizers to evaluate the incorporation of rice residues for supplying $\mathrm{K}$ as measured in terms of its effect on $\mathrm{K}$ uptake as well as rice yield.

\section{MATERIALS AND METHODS}

Field experiments were conducted at Bangladesh Institute of Nuclear agriculture (BINA) farm, Mymensingh, Bangladesh using the cropping pattern, BoroFallow-T. Aman during 2010-11 and 2011-12. The soil belongs to Sonatala series under the Agro Ecological Zone of Old Brahmaputra Floodplain of Bangladesh. The soil was silt loam in texture having soil $\mathrm{pH} 6.5$, organic matter content 0.98 and total $\mathrm{N} 0.09 \%$ and available P 13, exchangeable K 0.10 and available S 8 ppm. There were four treatments for the first crop (Boro rice): $\mathrm{T}_{1}-$ Control, $\mathrm{T}_{2}-50 \% \mathrm{NPKS}, \mathrm{T}_{3}-75 \%$ NPKS and $\mathrm{T}_{4}-100 \%$ NPK, respectively and this $100 \%$ NPKS rates was recommended on the basis of soil test value. $\mathrm{T}_{4}$ treated (100\%NPKS) plot of each block was further splitted into seven plots to represent seven treatments $\left(T_{4.1}\right.$ to $\left.T_{4.2}\right)$ 
for the second crop of T. Aman rice. The treatments for T. Aman rice were $\mathrm{T}_{1}$ Control, $\mathrm{T}_{2}-50 \%$ NPKS, $\mathrm{T}_{3}-75 \%$ NPKS and $\mathrm{T}_{4.1}-100 \%$ NPKS, $\mathrm{T}_{4.2}-100 \%$ NPS + $50 \% \mathrm{~K}+25 \%$ boro rice straw removed, $\mathrm{T}_{4.3}-100 \% \mathrm{NPS}+50 \% \mathrm{~K}+50 \%$ boro rice straw removed, $\mathrm{T}_{4.4}-100 \% \mathrm{NPS}+50 \% \mathrm{~K}+75 \%$ boro rice straw removed, $\mathrm{T}_{4.5}-100 \%$ $\mathrm{NPS}+75 \% \mathrm{~K}+25 \%$ boro rice straw removed, $\mathrm{T}_{4.6}-100 \% \mathrm{NPS}+75 \% \mathrm{~K}+50 \%$ boro rice straw removed and $\mathrm{T}_{4.7}-100 \% \mathrm{NPS}+75 \% \mathrm{~K}+75 \%$ boro rice straw removed, respectively. The experiment was laid out in a randomized complete block design (RCBD) with three replications (block) of each treatment. Each block was divided into ten unit plots for the selected cropping sequence. The unit plot size was $5 \mathrm{~m} \times 4 \mathrm{~m}$.

Rice cultivars for Boro and subsequent second crop T. Aman were used Binadhan-5 and Binadhan-7, developed in Bangladesh Institute of Nuclear agriculture. Forty and 25-day old seedlings for Boro and T. Aman rice were transplanted in the experimental plots maintaining 3 seedlings in each hill with a spacing of $20 \mathrm{~cm} \times 20 \mathrm{~cm}$. The recommended doses for N, P, K and S for Binadhan -5 were 140, 28, 48 and $22 \mathrm{~kg} \mathrm{ha}^{-1}$, respectively, and for Binadhan-7 the doses were 90 , 12,27 and $10 \mathrm{~kg} \mathrm{ha}^{-1}$, respectively. Fertilizers were applied as per treatment schedule. The full dose of each of triple superphosphate (TSP), muriate of potash (MoP), gypsum, zinc oxide and 1/3 of urea were applied at the time of final land preparation and rest of urea was applied equally splitted into two, equal splits, one after 15 and second at 35 days after transplanting (DAT). Intercultural operations such as irrigation and weeding were applied as and when required by the crop. Crop was harvested at full maturity. Grain yield was recorded on $14 \%$ moisture basis and straw yield on sun-dry basis. Five hills were randomly selected from each plot at maturity to record the yield contributing characters. Grain and straw samples were analyzed for the determination of K content (Knudsen et al., 1982). The K uptake by grain and straw was determined from $\mathrm{K}$ content and yield data. All the data were statistically analyzed by F-test and the mean differences were ranked by DMRT at 5\% level (Gomez and Gomez, 1984).

\section{RESULTS AND DISCUSSION}

First crop: Boro rice (var. Binadhan -5)

\section{Grain yield}

The grain yield of boro rice (var. Binadhan-5) was significantly influenced by different treatments imposed in the experiment in both years (Table 1). In 2010-11 the grain yield of Binadhan-5 varied from 2.33 to $6.00 \mathrm{t} \mathrm{ha}^{-1}$. The treatment $\mathrm{T}_{4}(100 \%$ NPKS) produced the highest grain yield of $6.00 \mathrm{t} \mathrm{ha}^{-1}$ while the lowest grain yield $\left(2.33 \mathrm{t} \mathrm{ha}^{-1}\right)$ was obtained in the treatment $\mathrm{T}_{1}$ (Control) which was $89 \%$ increase over control. In producing grain yield the treatment may be ranked in the order of $\mathrm{T}_{4}>\mathrm{T}_{3}>$ $\mathrm{T}_{2}>\mathrm{T}_{1}$. In 2011-12 the grain yield of Binadhan-5 varied from 2.25 to $6.24 \mathrm{t} \mathrm{ha}^{-1}$. The treatment $\mathrm{T}_{4}$ produced the highest grain yield while the lowest value was obtained 
from the treatment $T_{1}$ (control). These results are in agreement with Muangsri et al. (2008) who reported that application of rice straw and rice hull in combination with NPK fertilizer increased rice yield than that with NPK alone. Yield of rice grown on the soil amended with rice straw in combination with NPK fertilizers tended to be higher than that of rice grown on the soil amended with only NPK fertilizers.

\section{Straw yield}

Like grain yield, the straw yield of boro rice (var. Binadhan-5) responded significantly due to application of $\mathrm{K}$ (Table 1). In 2010-11 the straw yield varied from 2.43-6.75 $\mathrm{t} \mathrm{ha}^{-1}$. The highest straw yield $\left(6.75 \mathrm{t} \mathrm{ha}^{-1}\right)$ was recorded in $\mathrm{T}_{3}(75 \%$ NPKS) which was statistically similar to that of treatment $\mathrm{T}_{2}(50 \% \mathrm{NPKS})$ and treatment $\mathrm{T}_{4}\left(100 \%\right.$ NPKS) and the lowest straw yield $\left(2.43 \mathrm{t} \mathrm{ha}^{-1}\right)$ was observed in the $\mathrm{T}_{1}$ (Control). In 2011-12 the straw yield of Binadhan-5 varied from 2.50 to $7.50 \mathrm{t}$ $\mathrm{ha}^{-1}$ with the highest value in the treatment $\mathrm{T}_{3}$. Again, the treatment $\mathrm{T}_{1}$ produced the lowest straw yield. These results are in agreement with Bahmaniar et al. (2007) who found that different levels of potassium had positive effects on yield attributes, grain and straw yields of rice except harvest index and 1000-grain weight.

\section{Potassium uptake by grain and straw of Binadhan-5}

The $\mathrm{K}$ uptake by grain and straw as well as total $\mathrm{K}$ uptake by Binadhan- 5 was also significantly influenced by different treatments (Table 2). During 2010-11 the K uptake by grain varied from 4.62 to $16.88 \mathrm{~kg} \mathrm{ha}^{-1}$ while in straw it ranged from 30.30 to $106.09 \mathrm{~kg} \mathrm{ha}^{-1}$. The highest $\mathrm{K}$ uptake by grain $\left(16.88 \mathrm{~kg} \mathrm{ha}^{-1}\right)$ was recorded in $\mathrm{T}_{3}$ (75\% NPKS), which was statistically different from all other treatments while the lowest value $\left(4.62 \mathrm{~kg} \mathrm{ha}^{-1}\right)$ was observed in treatment $\mathrm{T}_{1}$. On the other hand the highest $\mathrm{K}$ uptake by straw (106.09 $\left.\mathrm{kg} \mathrm{ha}^{-1}\right)$ as well as total $\mathrm{K}$ uptake $\left(120.51 \mathrm{~kg} \mathrm{ha}^{-1}\right)$ was found in $\mathrm{T}_{4}(100 \% \mathrm{NPKS})$.

During 2011-12 the $\mathrm{K}$ uptake by grain varied from 4.28 to $13.73 \mathrm{~kg} \mathrm{ha}^{-1}$ while by straw it ranged from 32.77 to $127.5 \mathrm{~kg} \mathrm{ha}^{-1}$. The highest $\mathrm{K}$ uptake by grain (13.77 $\left.\mathrm{kg} \mathrm{ha}^{-1}\right)$ was recorded in $\mathrm{T}_{4}(100 \%$ NPKS), which was statistically similar to that of treatment $\mathrm{T}_{3}(75 \% \mathrm{NPKS})$. On the other hand the highest $\mathrm{K}$ uptake by straw $(127.5 \mathrm{~kg}$ $\left.\mathrm{ha}^{-1}\right)$ as well as total $\mathrm{K}$ uptake $\left(139.9 \mathrm{~kg} \mathrm{ha}^{-1}\right)$ was found in $\mathrm{T}_{3}(75 \% \mathrm{NPKS})$ which was statistically similar to that of treatment $\mathrm{T}_{4}(100 \%$ NPKS). The lowest values were found in $\mathrm{T}_{1}$ (control). These results are well corroborated with Mitra et al. (2001) who reported that the uptake of $\mathrm{K}$ was increased significantly with the increase in $\mathrm{K}$ levels for rice.

\section{Second Crop: T. Aman (Var. Binadhan-7) \\ Grain yield}

The grain yield of Binadhan-7 was also influenced significantly due to different treatments (Table 2). In 2010-11 the grain yield varied from 2.27 to $4.60 \mathrm{t} \mathrm{ha}^{-1}$. The highest grain yield $\left(4.60 \mathrm{t} \mathrm{ha}^{-1}\right)$ was obtained in $\mathrm{T}_{4.4}(100 \% \mathrm{NPS}+50 \% \mathrm{~K}+75 \%$ boro 
rice straw removed) while the lowest grain yield $\left(2.27 \mathrm{t} \mathrm{ha}^{-1}\right)$ was found in $\mathrm{T}_{1}$ (Control). The grain yield due to different treatments ranked in order of $\mathrm{T}_{4.4}>\mathrm{T}_{4.6}>$ $\mathrm{T}_{4.1}>\mathrm{T}_{4.3}>\mathrm{T}_{4.5}>\mathrm{T}_{4.7}>\mathrm{T}_{3}>\mathrm{T}_{4.2}>\mathrm{T}_{2}>\mathrm{T}_{1}$. It was also shown that the grain yield of Binadhan-7 in 2011-12 ranged from 2.33 to $4.87 \mathrm{t} \mathrm{ha}^{-1}$. The treatment $\mathrm{T}_{4.7}(100 \%$ NPS $+75 \% \mathrm{~K}+75 \%$ boro rice straw removed) gave the highest grain yield $(4.87 \mathrm{t}$ $\left.\mathrm{ha}^{-1}\right)$ while the lowest value $\left(2.33 \mathrm{t} \mathrm{ha}^{-1}\right)$ was obtained from the treatment $\mathrm{T}_{1}$. This might be due to the release of additional $\mathrm{K}$ from rice straw left in the land. These results somehow support the findings of Bachkaiya et al. (2007) who reported that the grain yield of rice was influenced markedly with differently levels of $\mathrm{K}$ and $200 \mathrm{~kg} \mathrm{~K} \mathrm{ha}^{-1}$ gave the highest grain yield.

\section{Straw yield}

The straw yield of T. Aman rice (var. Binadhan - 7) was significantly influenced by the different treatments (Table 5). The straw yield ranged from 3.87 to $7.60 \mathrm{t} \mathrm{ha}^{-1}$ in 2010-11 while in 2011-12 it varied from 3.53 to $6.93 \mathrm{t} \mathrm{ha}^{-1}$. In 2010-11 the highest straw yield was observed in $\mathrm{T}_{4.2}(100 \% \mathrm{NPS}+50 \% \mathrm{~K}+25 \%$ boro rice straw removed) while in 2011-12 the highest straw yield was observed in $\mathrm{T}_{4.7}(100 \%$ NPS $+75 \% \mathrm{~K}+75 \%$ boro rice straw removed). In both years the treatment $\mathrm{T}_{1}$ (Control) produced the lowest straw yield. This is supposed to be the addition of $\mathrm{K}$ from rice straw left in the land that exerted yield increase. Bahmaniar et al. (2007) also reported that $\mathrm{K}$ along with rice straw incorporation increased grain and straw yields of rice.

\section{Potassium uptake by grain and straw of Binadhan -7}

The $\mathrm{K}$ uptake by grain and straw as well as total $\mathrm{K}$ uptake of Binadhan-7 was also significantly influenced by the different treatments (Table 4). During 2010-11 the $\mathrm{K}$ uptake by grain varied from 4.52 to $16.52 \mathrm{~kg} \mathrm{ha}^{-1}$ while in straw it ranged from 34.73 to $77.09 \mathrm{~kg} \mathrm{ha}^{-1}$. The highest $\mathrm{k}$ uptake by grain and straw was recorded in $\mathrm{T}_{4.6}$ $(100 \%$ NPS $+75 \% \mathrm{~K}+50 \%$ boro rice straw removed), which was statistically different from all other treatments. The lowest $\mathrm{K}$ uptake was found in $\mathrm{T}_{1}(\mathrm{Control})$. On the other hand, the total $\mathrm{K}$ uptake ranged from 39.25 to $93.61 \mathrm{~kg}$ ha- ${ }^{1}$ with the highest value in treatment $\mathrm{T}_{4.6}$.

Table 4 also shows that the $\mathrm{k}$ uptake by grain, straw as well as total $\mathrm{K}$ uptake by Binadhan-7 during 2011-12 responded significantly due to different treatments. The highest $\mathrm{K}$ uptake by grain $\left(12.11 \mathrm{~kg} \mathrm{ha}^{-1}\right)$ was found in $\mathrm{T}_{4.6}(100 \% \mathrm{NPS}+75 \% \mathrm{~K}$ $+50 \%$ boro rice straw removed), while the lowest value $\left(3.50 \mathrm{~kg} \mathrm{ha}^{-1}\right)$ was observed in absolute control treatment. The total $\mathrm{K}$ uptake varied from $57.50-131.1 \mathrm{~kg} \mathrm{ha}^{-1}$. The highest total $\mathrm{K}$ uptake $\left(131.1 \mathrm{~kg} \mathrm{ha}^{-1}\right)$ was found in $\mathrm{T}_{4.3}(100 \% \mathrm{NPS}+50 \% \mathrm{~K}+$ $50 \%$ boro rice straw removed). The lowest total $\mathrm{K}$ uptake $\left(57.50 \mathrm{~kg} \mathrm{ha}^{-1}\right)$ was observed in $\mathrm{T}_{1}$. These results are well corroborated with Muangsri et al. (2008) who reported that the $\mathrm{K}$ uptake of rice without fertilizer was the lowest and application of rice hull in combination with NPK fertilizer increased K absorption and uptake than with NPK alone. 


\section{ECONOMIC ANALYSIS}

For economic analysis, the variable costs were considered and the fixed costs were ignored. Variable costs included variable money costs and variable opportunity costs. Variable money cost was the purchasing price of fertilizers and variable opportunity cost included the amount of money paid for carrying and broadcasting of fertilizers. Gross return was calculated as the total value of grain and straw. Table 5 shows the cost and benefit of different treatments used in the experiment. Among the treatments, $\mathrm{T}_{4.6}$ gave the highest benefit-cost ratio (4.38). The second highest benefitcost ratio was found in treatment $\mathrm{T}_{4.4}$ (4.32). The minimum benefit-cost ratio was observed in treatment $\mathrm{T}_{4.1}$ (3.49). Thus the use of $100 \% \mathrm{NPS}+75 \% \mathrm{~K}+50 \%$ Boro rice straw was found to be more effective and beneficial for $\mathrm{T}$. Aman rice production.

\section{CONCLUSION}

Rice straw in combination with $\mathrm{K}$ fertilizer could be a good option for supplying $\mathrm{K}$ for rice production in Bangladesh. The use of $100 \mathrm{~kg} \mathrm{~N} \mathrm{ha}^{-1}, 27 \mathrm{~kg}$ of $\mathrm{P}$ $\mathrm{ha}^{-1}, 48 \mathrm{~kg}$ of $\mathrm{K} \mathrm{ha}^{-1}, 22 \mathrm{~kg}$ of $\mathrm{S} \mathrm{ha}{ }^{-1}$ for Boro rice and $90 \mathrm{~kg} \mathrm{~N} \mathrm{ha}^{-1}, 27 \mathrm{~kg}^{-1} \mathrm{P} \mathrm{ha}^{-1}, 36$ $\mathrm{kg}$ of $\mathrm{K} \mathrm{ha}^{-1}, 10 \mathrm{~kg}$ of $\mathrm{S} \mathrm{ha}^{-1}$ and $50 \%$ rice straw removed from previous crop for $\mathrm{T}$. Aman can be the best treatment combination for the Boro-Fallow-T. Aman cropping pattern. However, similar study needs to be done in other areas of Bangladesh for location specific recommendation.

\section{REFERENCES}

Bachkaiya, V., Patil, S.K., Sarwgi, S.K. and Choudhary, V.K. 2007. Effect of potassium application on yield and potassium content and uptake in vertisols of chhattisgarh under rice- wheat cropping sequence. Environmental Ecology, 25(1): 89-91

Bahmaniar, M.A., Ranjbar, G.A. and Ahamafian, S.H. 2007. Effects of N and K applications on agronomic characteristics of two Iranian and landrace rice (Oryza sativa L.) cultivars. Journal of Biological Science, 10 (6): 880-886

Dobermann, A. and Fairhurst, T. 2000. Rice: nutrient disorders and nutrient management. Singapore and Los Banos (Phillipines): Potash and Phosphate Institute (PPI), Potash and Phosphate Institute of Canada (PPIC) and International Rice Research Institute (IRRI), pp.191

Gomez, K.A. and Gomez, A.A. 1984. Statistical Procedures for Agricultural Research. John Wilely and Sons. New York

Knudsen, D., Peterson, G.A. and Pratt, P.F. 1982. Lithium, Sodium and Potassium. In methods of Soil Analysis Part 2 edited by Page et al., American Society of Agronomy, Inc. Publisher, USA, pp. 225-245

Mitra, G. N., Sahoo, D., and Rout, K.K. 2001. Effect of N-K interaction on yield, nutrient uptake and grain quality of rice- groundnut cropping sequence in the alluvial soil of Orissa. Journal of Potassium Research, 17 (1-4): 71-78 
Muangsri, M., Chanchareonsook, J. and Sarobol, E. 2008. Effect of rice straw and rice hull in combination with nitrogen phosphorus and potassium fertilizer on yield of rice grown on phimai soil series. Proceeding of the 46th Kasetsart University Annual Conference, Kasetsart 29 Jan 1 Feb 2008 Subject: Plant, 82-89

Rao, Y. Jan, L.Y. and Jan, Y.N. 1990. Similarity of the product of the Drosophila neurogenic gene big brain to transmembrane channel proteins. Nature,345 (6271): 163-167

Sairam, R.K. Rao, K.V. and Srivastava, G.C. 2002. Differential response of wheat genotypes to long term salinity stress in relation to oxidative stress, antioxidant activity and osmolyte concentration. Plant Science, 163: 1037-1046

Singh, G.R., Dixit, R.S. and Dwivedi, A.P. 2006. Effect of nitrogen, phosphorus and potassium levels on growth, yield and quality of hybrid rice (Oryza sativa L.) Agronomy, 43(1): 64-66 
Table 1: Grain and straw yield of Boro rice (var. Binadhan-5) as influenced by different levels of $K$

\begin{tabular}{l|c|c|c|c}
\hline \multirow{2}{*}{ Treatment } & \multicolumn{2}{|c|}{ Grain yield $\left(\mathbf{t ~ h a} \mathbf{~}^{-\mathbf{1}}\right)$} & \multicolumn{2}{c}{ Straw yield $\left(\mathbf{t ~ h a}^{\mathbf{- 1}}\right)$} \\
\cline { 2 - 5 } & $\mathbf{2 0 1 0 - 1 1}$ & $\mathbf{2 0 1 1 - 1 2}$ & $\mathbf{2 0 1 0 - 1 1}$ & $\mathbf{2 0 1 1 - 1 2}$ \\
\hline $\mathrm{T}_{1}($ Control $)$ & $2.33 \mathrm{c}$ & $2.25 \mathrm{c}$ & $2.43 \mathrm{~b}$ & $2.50 \mathrm{c}$ \\
$\mathrm{T}_{2}(50 \% \mathrm{NPKS})$ & $4.40 \mathrm{~b}$ & $4.13 \mathrm{~b}$ & $6.38 \mathrm{a}$ & $6.25 \mathrm{~b}$ \\
$\mathrm{~T}_{3}(75 \% \mathrm{NPKS})$ & $4.87 \mathrm{~b}$ & $4.95 \mathrm{ab}$ & $6.75 \mathrm{a}$ & $7.50 \mathrm{a}$ \\
$\mathrm{T}_{4}(100 \% \mathrm{NPKS})$ & $6.00 \mathrm{a}$ & $6.24 \mathrm{a}$ & $6.53 \mathrm{a}$ & $7.17 \mathrm{ab}$ \\
$\mathrm{CV}(\%)$ & 9.29 & 10.67 & 9.85 & 9.16 \\
$\mathrm{SE}( \pm)$ & 0.41 & 0.27 & 0.54 & 0.308 \\
\hline
\end{tabular}

In a column, figure (s) followed by the same letter (s) do not differ significantly at 5\% level by DMRT, SE $( \pm)$ - Standard error of means

Table 2: Effect of $\mathrm{K}$ on the potassium uptake by grain and straw of Boro rice

\begin{tabular}{l|c|c|c|c|c|c}
\hline \multirow{2}{*}{ Treatment } & \multicolumn{6}{|c}{ K uptake (kg ha $\left.{ }^{-1}\right)$} \\
\cline { 2 - 7 } & \multicolumn{3}{|c|}{$\mathbf{2 0 1 0 - 1 1}$} & \multicolumn{3}{c}{$\mathbf{2 0 1 1 - 1 2}$} \\
\cline { 2 - 8 } & Grain & Straw & Total & Grain & Straw & Total \\
\hline $\mathrm{T}_{1}($ Control) & $4.62 \mathrm{c}$ & $30.30 \mathrm{~b}$ & $34.92 \mathrm{~b}$ & $4.28 \mathrm{c}$ & $32.77 \mathrm{c}$ & $37.03 \mathrm{c}$ \\
$\mathrm{T}_{2}(50 \% \mathrm{NPKS})$ & $12.73 \mathrm{~b}$ & $72.11 \mathrm{c}$ & $84.84 \mathrm{c}$ & $8.26 \mathrm{~b}$ & $102.5 \mathrm{~b}$ & $110.7 \mathrm{~b}$ \\
$\mathrm{~T}_{3}(75 \%$ NPKS $)$ & $16.88 \mathrm{a}$ & $82.47 \mathrm{~b}$ & $99.35 \mathrm{~b}$ & $12.38 \mathrm{a}$ & $127.5 \mathrm{a}$ & $139.9 \mathrm{a}$ \\
$\mathrm{T}_{4}(100 \% \mathrm{NPKS})$ & $14.42 \mathrm{~b}$ & $106.09 \mathrm{a}$ & $120.51 \mathrm{a}$ & $13.73 \mathrm{a}$ & $125.1 \mathrm{a}$ & $138.9 \mathrm{a}$ \\
$\mathrm{CV}(\%)$ & 2.67 & 4.71 & 7.71 & 8.71 & 4.50 & 4.29 \\
$\mathrm{SE}( \pm)$ & 1.42 & 8.36 & 9.59 & 0.482 & 2.52 & 2.64 \\
\hline
\end{tabular}

In a column, figure (s) followed by the same letter (s) do not differ significantly at $5 \%$ level by DMRT, SE $( \pm)$ - Standard error of means 
Table 3: Grain and straw yield of T. Aman (var. Binadhan-7) as influenced by different levels of $K$

\begin{tabular}{c|cc|c|c}
\hline \multirow{2}{*}{ Treatment } & \multicolumn{2}{|c|}{ Grain yield $\left(\mathbf{t ~ h a}^{-\mathbf{1}}\right)$} & \multicolumn{2}{c}{ Straw yield $\left(\mathbf{t ~ h a}^{-\mathbf{1}}\right)$} \\
\cline { 2 - 5 } & $\mathbf{2 0 1 0 - 1 1}$ & $\mathbf{2 0 1 1 - 1 2}$ & $\mathbf{2 0 1 0 - 1 1}$ & $\mathbf{2 0 1 1 - 1 2}$ \\
\hline $\mathrm{T}_{1}$ & $2.27 \mathrm{~d}$ & $2.33 \mathrm{c}$ & $3.87 \mathrm{f}$ & $3.53 \mathrm{c}$ \\
$\mathrm{T}_{2}$ & $3.80 \mathrm{c}$ & $3.50 \mathrm{~b}$ & $5.90 \mathrm{de}$ & $5.25 \mathrm{a}$ \\
$\mathrm{T}_{3}$ & $4.33 \mathrm{ab}$ & $4.10 \mathrm{ab}$ & $5.70 \mathrm{e}$ & $6.48 \mathrm{a}$ \\
$\mathrm{T}_{4.1}$ & $4.40 \mathrm{ab}$ & $4.37 \mathrm{ab}$ & $6.30 \mathrm{cde}$ & $6.73 \mathrm{a}$ \\
$\mathrm{T}_{4.2}$ & $4.10 \mathrm{bc}$ & $4.27 \mathrm{ab}$ & $7.60 \mathrm{a}$ & $6.51 \mathrm{a}$ \\
$\mathrm{T}_{4.3}$ & $4.37 \mathrm{ab}$ & $4.33 \mathrm{ab}$ & $7.20 \mathrm{ab}$ & $7.30 \mathrm{a}$ \\
$\mathrm{T}_{4.4}$ & $4.60 \mathrm{a}$ & $4.53 \mathrm{ab}$ & $6.70 \mathrm{bcd}$ & $6.75 \mathrm{a}$ \\
$\mathrm{T}_{4.5}$ & $4.33 \mathrm{ab}$ & $4.20 \mathrm{ab}$ & $6.70 \mathrm{bcd}$ & $6.42 \mathrm{a}$ \\
$\mathrm{T}_{4.6}$ & $4.47 \mathrm{ab}$ & $4.60 \mathrm{ab}$ & $6.60 \mathrm{bcd}$ & $6.28 \mathrm{a}$ \\
$\mathrm{T}_{4.7}$ & $4.33 \mathrm{ab}$ & $4.87 \mathrm{a}$ & $7.10 \mathrm{abc}$ & $6.93 \mathrm{a}$ \\
$\mathrm{CV}(\%)$ & 6.31 & 9.71 & 6.92 & 8.48 \\
$\mathrm{SE}( \pm)$ & 0.13 & 0.325 & 0.20 & 0.304 \\
\hline
\end{tabular}

In a column, figure (s) followed by the same letter (s) do not differ significantly at 5\% level by DMRT, SE $( \pm)$ - Standard error of means 
Table 4: Effect of $K$ on the potassium uptake by grain and straw of T. Aman rice

\begin{tabular}{c|l|c|c|c|c|c}
\hline \multirow{2}{*}{ Treatment } & \multicolumn{5}{c}{ K uptake (kg ha $\left.{ }^{-1}\right)$} \\
\cline { 2 - 7 } & \multicolumn{5}{c}{ 2010-11 } & \multicolumn{3}{c}{$\mathbf{2 0 1 1 - 1 2}$} \\
\cline { 2 - 7 } & Grain & Straw & Total & Grain & Straw & Total \\
\hline $\mathrm{T}_{1}$ & $4.52 \mathrm{~g}$ & $34.73 \mathrm{~d}$ & $39.25 \mathrm{~d}$ & $3.50 \mathrm{f}$ & $54.0 \mathrm{e}$ & $57.50 \mathrm{f}$ \\
$\mathrm{T}_{2}$ & $10.54 \mathrm{ef}$ & $62.08 \mathrm{c}$ & $72.62 \mathrm{c}$ & $7.00 \mathrm{e}$ & $85.54 \mathrm{~d}$ & $92.54 \mathrm{e}$ \\
$\mathrm{T}_{3}$ & $11.38 \mathrm{de}$ & $70.31 \mathrm{abc}$ & $81.69 \mathrm{bc}$ & $8.01 \mathrm{cde}$ & $105.0 \mathrm{c}$ & $113.2 \mathrm{~d}$ \\
$\mathrm{~T}_{4.1}$ & $9.18 \mathrm{f}$ & $71.67 \mathrm{ab}$ & $80.85 \mathrm{bc}$ & $7.42 \mathrm{de}$ & $109.6 \mathrm{bc}$ & $116.2 \mathrm{~cd}$ \\
$\mathrm{~T}_{4.2}$ & $14.59 \mathrm{~b}$ & $67.63 \mathrm{bc}$ & $82.22 \mathrm{~b}$ & $9.46 \mathrm{bc}$ & $107.5 \mathrm{bc}$ & $115.6 \mathrm{~cd}$ \\
$\mathrm{~T}_{4.3}$ & $12.62 \mathrm{~cd}$ & $73.90 \mathrm{ab}$ & $86.52 \mathrm{ab}$ & $9.01 \mathrm{~cd}$ & $123.3 \mathrm{a}$ & $131.1 \mathrm{a}$ \\
$\mathrm{T}_{4.4}$ & $13.54 \mathrm{bc}$ & $75.92 \mathrm{ab}$ & $89.46 \mathrm{ab}$ & $11.15 \mathrm{ab}$ & $111.4 \mathrm{~b}$ & $120.5 \mathrm{bc}$ \\
$\mathrm{T}_{4.5}$ & $11.33 \mathrm{de}$ & $72.39 \mathrm{ab}$ & $83.72 \mathrm{~b}$ & $7.95 \mathrm{cde}$ & $107.2 \mathrm{bc}$ & $114.3 \mathrm{~d}$ \\
$\mathrm{~T}_{4.6}$ & $16.52 \mathrm{a}$ & $77.09 \mathrm{a}$ & $93.61 \mathrm{a}$ & $12.11 \mathrm{a}$ & $108.8 \mathrm{bc}$ & $120.3 \mathrm{bc}$ \\
$\mathrm{T}_{4.7}$ & $9.60 \mathrm{f}$ & $74.04 \mathrm{ab}$ & $83.64 \mathrm{~b}$ & $7.84 \mathrm{cde}$ & $118.6 \mathrm{a}$ & $126.4 \mathrm{~b}$ \\
$\mathrm{CV}_{(\%)}$ & 5.28 & 3.40 & 5.29 & 8.24 & 2.82 & 2.80 \\
$\mathrm{SE}_{( \pm)}$ & 0.60 & 2.31 & 2.78 & 0.58 & 1.67 & 1.78 \\
\hline
\end{tabular}

In a column, figure (s) followed by the same letter (s) do not differ significantly at $5 \%$ level by DMRT, SE $( \pm)$ - Standard error of means 
Table 5: Production economic analysis of Boro-Fallow-T. Aman cropping pattern

\begin{tabular}{|c|c|c|c|c|c|c|c|}
\hline \multirow[t]{2}{*}{$\begin{array}{l}\text { Treat } \\
\text { ment }\end{array}$} & \multicolumn{2}{|c|}{$\begin{array}{c}\text { Economic Yield } \\
\qquad\left(\mathrm{kg} \mathrm{ha}^{-1}\right)\end{array}$} & \multirow{2}{*}{$\begin{array}{c}\text { Gross } \\
\text { return } \\
(\mathrm{Tk})\end{array}$} & \multirow{2}{*}{$\begin{array}{c}\text { Added } \\
\text { cost over } \\
\text { control } \\
\text { (Tk) }\end{array}$} & \multirow{2}{*}{$\begin{array}{c}\text { Added } \\
\text { benefit } \\
\text { over } \\
\text { control } \\
\text { (Tk) }\end{array}$} & \multirow{2}{*}{$\begin{array}{c}\text { Gross } \\
\text { margin } \\
\text { over } \\
\text { control } \\
(\mathrm{Tk})\end{array}$} & \multirow[t]{2}{*}{ MBCR } \\
\hline & Grain & Straw & & & & & \\
\hline $\mathrm{T}_{1}$ & 4590 & 6165 & 75015 & - & - & - & - \\
\hline $\mathrm{T}_{2}$ & 6915 & 8862 & 112587 & 8887 & 37572 & 28685 & 4.23 \\
\hline $\mathrm{T}_{3}$ & 8025 & 12213 & 132588 & 13331 & 57573 & 44242 & 4.30 \\
\hline $\mathrm{T}_{4.1}$ & 8270 & 13030 & 137080 & 17775 & 62065 & 44290 & 3.49 \\
\hline $\mathrm{T}_{4.2}$ & 8370 & 14100 & 139650 & 17025 & 64635 & 47610 & 3.80 \\
\hline $\mathrm{T}_{4.3}$ & 8700 & 14500 & 145000 & 17025 & 69985 & 52960 & 4.11 \\
\hline $\mathrm{T}_{4.4}$ & 9013 & 13450 & 148645 & 17025 & 73630 & 56605 & 4.32 \\
\hline $\mathrm{T}_{4.5}$ & 8530 & 13120 & 141070 & 17400 & 66055 & 48655 & 3.80 \\
\hline $\mathrm{T}_{4.6}$ & 9200 & 14030 & 152030 & 17600 & 77015 & 59415 & 4.38 \\
\hline $\mathrm{T}_{4.7}$ & 9070 & 12880 & 148930 & 17400 & 73915 & 56515 & 4.25 \\
\hline
\end{tabular}

